\title{
AN EXPLORATORY STUDY OF LEADERSHIP AND ORGANIZATIONAL BEHAVIOR ON WORKERS' PERFORMANCE: OLAWIL WIRE INDUSTRY OSOGBO, OSUN STATE
}

\author{
Mufutau Akanmu Popoola \\ PhD In Business Administration \\ Department of Business and Entrepreneurship \\ Kwara State University, Malete, Nigeria \\ 28, Oyedokun Street, Agowande Area, \\ Igbona, Osogbo, Osun State \\ e-mail: mufupop@yahoo.com \\ ORCID: https://orcid.org/0000-0003-1483-5124
}

\begin{abstract}
Leadership and organizational behavior on workers performance has direct and indirect influence on organization profitability whether public or private organization. Effective leadership is a crucial to organization growth. The central focus of this paper is to examine in detail how leadership and organizational behavior influence workers' performance in Olawil wire industry limited Osogbo. The intention was to find a link between managerial leadership styles and employee job satisfaction. Following the review of the literature about leadership styles and employee performance, and the relation between the two, it was noticed that no studies had looked at the impact of managerial leadership style on employee performance in Nigeria. The work is an exploratory research design and adopts interviews as source of data collection. Thirty administrative Olawil staff were selected. My finding indicates that there are relationships between leadership style and workers performance in Olawil industry Osogbo, roles play by leadership cannot be quantified. The management guiding members on how to perform well, providing the facilities necessary for the performance of the workers activities, matching people properly with the activities they perform, rewarding people on the basis of their contribution towards the achievement of the organization goals and objective as well as aid effectiveness of management decision on workers performance. Equal opportunities are given to everyone to advance and progress on their chosen career. Workshops within the State were given to some selected staff to boost their profession. The study, therefore, recommended that, the leaders should improve in interpersonal relationship between the staff and the management team to ensure increase in performance and productivity.
\end{abstract}

Keywords: leadership, organization, behavior, management and performance.

\section{Introduction}

\section{Background to the Study}

Leadership is a process in which a leader attempts to influence his or her followers to establish and accomplish a goal. Leadership is valued in our culture, especially when it helps to achieve goals that are beneficial to the population, such as the enactment of effective and preventive healthy policies. An individual with leadership qualities can also improve an organization and the individual in it, whether it be a teacher who works to get better teaching materials and after school programs or an employee who develops new ideas of products and influences other to invest in them (Jamaludin, 2011)

Leadership can exhibited in a variety of ways and circumstances. Mothers and fathers show leadership in raising their children with good values and encouraging them to develop to their potential. Teachers show it in inspiring students to learn and to develop their intellectual capacity. Health care workers can be leaders and develop services that meet the needs of the communities they serve, or work in collaboration with other organization to create cost effective, prevention oriented programme and services. Many studies have been done, books and articles have been published on this subject, through this work, a consistent set of leadership attributes has emerged. An effective leader does most, if not all of the following:
Challenge the Process: searchoutchallenging opportunities, take risks and learn from mistakes. Inspire others to come together and agree on a future direction or goal, create a shared vision by thinking about the future, having a strong positive vision, and encouraging others to participate.

Help others to act: Help others to work together, to cooperate and collaborate by developing shared goals and building trust and help to make others stronger by encouraging them to develop their skills and talents. Set an example to his or her followers and encourage others to recognize each individual's contributions to the success of a project. It could be observed that leadership and management envisages deeply into what the organization can achieve if the quality of recognition is accorded to them. Leadership has been propounded to include the sources of the influence that are built into a position in an organizational hierarchy.

These include organizationally sectioned, reward and punishment, authority as well as reference and expert power by Katz and Kahn (1996). It could be seen however that subordinates within the organization, through not all seem to enjoy the influence that exists all over and above the organization. Leadership is very essential in organization and greatly influences the whole organization because achievements and results occurs corollary to the traits being projected by the leader. 
Leadership includes the ultimate source of power but has that positive ability in persuading other individuals and to be innovative in decision making.

\section{Statement of the Research Problem}

Some leaders do not appreciate the fact that employees have to be motivated to ensure they do what they have to do so that the goals and objectives of the organizations are achieved. Because of the prevailing situation in Nigeria where supply of labour is greater than its demand, and every organization has a distinct leadership style, some employers do not believe much in effective motivation of workers to produce high performance. They uphold the view that even if workers are not properly motivated, they cannot leave the job since there is no job in the labor market. Most employers are not effective in their leadership behavior and this has negative impact in their organization growth. They treat workers as machines believing that workers could be treated anyhow; some leaders do not also manage their time effectively with their workers to enhance effective job performance from the workers. In response to this, workers do not handle their properly.

\section{Objective of the study}

The central focus of this paper is to examine in detail how leadership and organizational behavior influence workers' performance in Olawil wire industry limited Osogbo.

\section{Literature Review}

\section{Conceptual Clarification}

Concept of Leadership

Leadership is the integrated sharing of vision, resources and value to indicate positive change. Leadership is defined in many different ways that it is hard to come up with a single working definition. Leadership is not just a person or group of people in high position, understanding leadership is not complete without understanding interaction between a leader and his or her follower. Many people have defined leadership differently. For instance, James C. Georges, of the Par Training Corporation says "Leadership is the ability to obtain followers", while Keith Davis define leadership as "the ability to persuade others to seek defined objectives enthusiastically. It is the human factor which binds a group together and motivates it towards goals. Popoola (2014) explained that leadership has to do with casting vision and motivating people, and a leader needs to influence the behavior of others. Korabik and Ayman (2007) view leadership as a transaction between one person (leader) and another person (subordinate), while Ngodo (2008) perceives leadership to be a reciprocal process of social influence, in which leaders and subordinates influence each other in order to achieve organizational goals. For instance, a leadership style is view as the combination of traits, characteristics, skills and behavior that leaders use when interacting with their subordinates (Marturano and Gosling, 2008). Also in Popoola (2014), leadership is a process in which a leader attempts to influence his or her 122 followers to establish and accomplish a goal. In order to accomplish these goals, the leader exercises his or her power to influence people. That power is exercised in earlier stages by motivating followers to get the job done and in later stages by rewarding or punishing those who do or not perform to the level of expectation. Leadership is a continuous process, with the accomplishment of one goal becoming the beginning of a new goal. The proper reward by the leader is of utmost importance in order to continually motivate followers in the process.But leadership is generally defined simply as influenced, "the art of process of influencing people so that they will strive willingly toward the achievement of group goals"(Koontz, O'Donnell\&Weihrich). Leadership occurs when one person "induces" and "inspires" others to work toward predetermined objectives.

- To lead is to guide, conduct, direct and precede.

- Leaders act to help a group achieve objectives with the maximum application of its capabilities.

- $\quad$ Leaders do not stand behind a group to push and to prod; they place themselves before the group as they facilitate progress and inspire the group to accomplish organizational goals.

What does leadership do for an organization? If we defined leadership as a process involving interactions between a leader and followers, usually subordinate employees of a company, leadership profoundly affects the company. Another vital role of leadership is to represent the group or organization and link it to the external world in order to obtain vital resources to carry out its mission. When necessary, leadership has to defend the organization.

Impact of Leadership Styles in Workers' performance

By leadership style, it means the way in which the functions of leadership are carrier out, the way in which the manager typically behaves towards members of the group to achieve organizational goals and objectives. In order to get the results from subordinates, the manager must also have regard for the need to encourage high morale, a spirit of involvement and co-operation and a willingness to work.

This gives rise to the style of leadership and provides another rubric under which leadership behavior can be analyzed.

Broad classification of leadership style: there are many possible ways of describing leadership such as for example, dictatorial, unitary, charismatic, benevolent, bureaucratic, consultative, and participative. The style of leadership towards subordinated staff and focus of power can be classified within broad threefold headings.

(a) Authoritarian (orautocratic) style: Here, the focus of power is with the manager and all interactions within the group move towards the manager. The manager alone exercise decision 
making and authority for determining policy, procedure, for achieving goals work tasks and relationship, control of rewards or punishment. This may have impact on organizational productivity provided that the managers have capability to carry out operational activities of the firm. Subordinates under this style do what they are told to do so as not to lose the means (in terms of salary, increase promotion etc.).

(b) Democratic/Participative Style: This approach seeks to obtain the cooperation of workers in achieving organizational goals by allowing them to participate in decision making. It was believed that workers would support a decision they were involved. The democratic or participative leader is characterized by employee-oriented, democratically supportive behaviors. He uses general supervision and he is considerate of his subordinates. He is group centered. He consults with his subordinates on problems, tasks and goals that face him and the group as a whole. He encourages participation in matters or decisions affecting his subordinates. He is particularly relationship-oriented. $\mathrm{He}$ is willing to share responsibility in both planning and execution.

\section{Democratic style shows:}

- Consideration for subordinates - He treats them with dignity and kindness. He is non-punitive in his dealings with them.

- Consultative decision making - frequently asks subordinates for their opinions on issues before he makes vital decisions.

- General supervision - His supervisory style is in a general rather than in a close manner. He delegates authority to his subordinates and permits freedom to exercise discretion in their work. He does not believe in imposition of tight controls and close supervision.

However, Democratic/participative leadership style is most effective only when:

- Decisions are not routine in nature

- Decisions need to be made rapidly, this allowing time to involve subordinates in the decision process.

- The information required for effective decision making cannot be standardized or centralized.

- Subordinates feel a strong need for independence.

- Subordinates regard their participation in decision making as legitimate.

- Subordinates see themselves as able to contribute to the decision making process.

- Subordinates are confident of their ability to work without close supervision.)

(c) Laissez-Faire Leadership: The laissez-faire or free-rein style of leadership does not depend on the leader to provide external motivation as do the autocratic and participate styles. The workers motivate themselves based on their needs, wants and desires. They are given a goal and left mostly up to their own to achieve it, using their ingenuity. The leader principally assumes the role of a group member.

Everything is so supportive that only positive information is passed along. He allows subordinates to set their own goals/quotes. He allows absolutely free hand in the process of decision making.

\section{Theoretical Clarification}

\section{The Situational Theory Leadership}

This approach believes that leadership is the product of situations in particular groups. The argument by the proponents of this theory is that leadership will differ in each group situation. The situation in which the leader finds himself is thus more important than what he does or what he is. This concept of situation means that leadership is specific and relative to the situation in which it occurs. Therefore, it will be seen that the management style that is most meaningful in any situation is a function of multitudes of relevant variables such as:

- What the position of the leader is in the hierarchy

- How much power is accorded that position

- What type of people work in the system

- What kind of business it is

- What is the environment of the business

- What is the nature of organizational climate

- In what national culture is the organization located

Thus, because of these variables, it is a bit (if not exceedingly) difficult to develop a single leadership standard. However, no matter which ever style is adopted and ideal leader must be sensitive, adaptive and flexible to get subordinates to put up their best so he can get the work done through other people effectively.

Fielder's Situational Control Theory of Leadership: Fielder's theory states that the group's performance will be contingent upon the appropriate matching of leadership styles and the degree of favorableness of the group situation for the leader, that is, the degree to which the situation provides the leader with influence over his group members.

The leader's effectiveness is partially contingent upon three variables:

1. The leader-member relations

2. The task-structure

3. The leader's position power

a. The leader-member relations refer to the extent to which the leader is accepted by the group. In some cases, the personalities of both the leader and the led affect these relations. In situations where the leader and his group get along well, the leader has greater influence than where he is disliked.

b. The task structure refers to the degree to which the task is structured or unstructured. The more the task is structured or routine, the easier it is for the manager to lead and get compliance from his group. Unstructured tasks call for more creative leaders and make leading much more difficult. 
c. The leaders position power refers to the leader's former power provided for that position by the formal organization. The more power he has to reward or punish, the more influence he will have.

\section{Empirical Clarification}

There are many empirical evidence relating to leadership and organization behavior in an organization. In his work, Jamaludin (2011) conducted their research on the leadership and their styles and suggested that effective leaders are those who use their powers for betterment of the followers and organizations as well. Leaders are one of the major key drivers in enhancing the production and innovations. According to Raelin (2011), Leadership is directly connected to the practices to which people are dedicated. The most substantial of leaders is their influential personality that has positive relation with the follower's job satisfaction and the performance.

\section{Research Methodology}

The study is an exploratory research design, and researcher's philosophy is epistemology with positivism perspectives. The researcher collected data through the use of interview which was conducted on thirty senior administrative of Olawil wire industry limited Osogbo. Qualitative technique was used in this research in line with Abdulraheem (2016) who noted Corbin and Strauss submission that; Qualitative research is germane when the researcher intends to comprehend the inner experience of the certain study.

\section{Discussion of findings}

The researcher conducted interview on selected workers on Olawil wire industry limited Osogbo. Researcher finding indicates that there are relationship between leadership style and workers performance in organization as a result of roles play by Olawil management on leadership style cannot be quantified because they guide members on how to perform well, providing the facilities necessary for the performance of the workers activities, matching people properly with the activities they perform, rewarding people on the basis of their contribution towards the achievement of the organization goals and objectives as well as aid effectiveness of management decision on workers performance. In the same vein, equal opportunities are given to everyone to advance and progress on their career. Workshops within the state are given to some selected staff to boost their profession.

In addition, effective leadership by Ezeh (2008) did analysis and gives evidence in the favour of transactional effective leadership, they observed that transactional leadership is more effective when organization desire to achieve their aims and objectives. Supervisors play a vital role in job satisfaction as seen in Olawil wire industry Osogbo. In other words, transactional leadership encourages followers to perform according to the leader's expectation and get rewards and promotion. Ample support is available in the leadership literature according to (Avolio, Bass and Jung,1999) to make transactional leadership more effective, appropriate usage of contingent reward is an important feedback to assemble expectations with followers in term of their performance. Facilitating the followers to be familiar with job obligations and recognized objectives to achieve estimated degree of performance is an important aspect of transactional leadership style (Lo, Ramayah and Min, 2009). (Janssen and Yperen, 2004) acknowledged that transactional leadership assists the efficiency by enhancing innovative job performance and job satisfaction. Hence, the study shows that effective leadership has significant impact on employee performance and job satisfaction in Olawil industry Osogbo.

\section{Conclusion}

Following the review of the literature about leadership styles and employee performance, and the relation between the two, it was noticed that no studies had looked at the impact of managerial leadership style on employee performance in Nigeria. Based on the literature review, it was predicted that leadership styles would differ according to managers demographic profiles and similarly that employee job satisfaction would also be influenced by demographic profiles. The intention was to find a link between managerial leadership styles and employee job satisfaction. The findings indicated that there were indeed significant differences in leadership style in use by the organizations under review and employees of these organizations. The study found that there were also significant differences in leadership style due to managers' demographic characteristics, and that the democratic leadership style was preferred among managers, in contrast to suggestions that business managers prefer to be autocratic. The outcomes showed that the relationship between leadership style and employees performance in Olawil industry Osogbo is cordial and this lead to higher productivity in the organization.

\section{Recommendations}

The following recommendations are suggested based on the findings.

(i) The leader should improve in interpersonal relationship between the staff and management team to ensure increase in productivity.

(ii) There should be a free flow of information to ensure cohesion.

(iii) The management team should always have the welfare of the workers at heart.

(iv) The management team should create an enabling environment that will enhance workers participation in the day-to-day running of the business.

(v) The leader should ensured that their employees are well directed, coordinated appraised, and leading them toward achieving the organizational goals and objectives. 


\section{ДОСЛІДЖЕННЯ ЛІДЕРСТВА ТА ОРГАНІЗАЦІЙНОЇ ПОВЕДІНКИ РОБІТНИКІВ: OLAWIL WIRE INDUSTRY OSOGBO, ШTAT OСУH}

Муфутау Аканму Попоола, доктор філософії з бізнес-адміністрування, кафедра бізнесу та підприємництва, Державний університет Квара, Малете, Нігерія, Вулиця Ойодокун 28, район Агованде, Ігбона, Ошогбо, штат Осун, e-mail: mufupop@yahoo.com, ORCID: https://orcid.org/0000-0003-1483-5124

Лідерство - це процес, в якому лідер намагається вплинути на своїх послідовників, щоб встановити мету і досягти ії. Лідерство та організаційна поведінка працівників має прямий та непрямий вплив на продуктивність та прибутковість як державної, так і приватної організації. Ефективне лідерство $є$ вирішальним для економічного зростання організації. Основна увага в цій роботі зосереджена на тому, щоб детально вивчити, як лідерство та організаційна поведінка впливають на працездатність працівників дротової промисловості Olawil в Ошогбо. Метою було знайти зв'язок між стилями керівництва та задоволеністю роботою працівників. Після огляду літератури про стилі лідерства та працездатності працівників, а також співвідношення між ними, було відмічено, що жодне дослідження не розглядало вплив стилю керівництва на продуктивність працівників у Нігерії. Робота $є$ науковою розробкою з використанням інтерв'ю як джерела збору даних. Були відібрані тридцять адміністративних співробітників Olawil. Висновок полягає в тому, що існує залежність між стилем керівництва та діяльністю працівників в Olawil, роль якої не може бути кількісно визначена. Надано рекомендації керівництву щодо того, як добре працювати, забезпечуючи робітників засобами, необхідними для виконання завдань, належним чином узгоджуючи людей з діяльністю, яку вони виконують, винагороджуючи їх на основі внеску кожного в досягнення цілей організації. Рівні можливості надаються кожному для просування та прогресу в обраній кар'єрі. Деякі працівники провели семінари в межах держави для популяризації їхньої професії. Отже, нашим дослідженням рекомендовано, щоб управлінські кадри поліпшили міжособистісні відносини між персоналом та керівною командою для забезпечення підвищення продуктивності.

Ключові слова: лідерство, організація, поведінка, управління та продуктивність.

\section{ИССЛЕДОВАНИЕ ЛИДЕРСТВА И ОРГАНИЗАЦИОННОГО ПОВЕДЕНИЯ РАБОТНИКОВ: OLAWIL WIRE INDUSTRY OSOGBO, ШTAT ОСУН}

Муфутау Аканму Попоола, доктор фрилософии по бизнес-администрированию, кафедра бизнеса и предпринимательства, Государственный университет Квара, Малете, Нигерия, Улица Ойодокун, 28 район Агованде, Игбона, Ошогбо, штат Осун, e-mail: mufupop@yahoo.com, ORCID: https://orcid.org/0000-0003-1483-5124

Лидерство - это процесс, в котором лидер пытается повлиять на своих последователей, чтобы установить цель и достичь ее. Лидерство и организационное поведение работников имеет прямое и косвенное влияние на производительность и прибыльность как государственной, так и частной организации. Эффективное лидерство является решающим для экономического роста организации. Основное внимание в этой работе сосредоточено на том, чтобы детально изучить, как лидерство и организационное поведение влияют на работоспособность работников проводной промышленности Оlawil в Ошогбо. Целью было найти связь между стилями руководства и удовлетворенностью работой сотрудников. После обзора литературы о стиле лидерства и работоспособности работников, а также соотношение между ними, было отмечено, что ни одно исследование не рассматривало влияние стиля руководства на производительность работников в Нигерии. Работа является научной разработкой с использованием интервью как источника сбора данных. Были отобраны тридцать административных сотрудников Olawil. Вывод заключается в том, что существует зависимость между стилем руководства и деятельностью работников в Olawil, роль которой не может быть количественно определена. Даны рекомендации руководству о том, как работать, обеспечивая рабочих средствами, необходимыми для выполнения задач, должным образом согласовывая людей с деятельностью, которую они выполняют, вознаграждая их на основе вклада каждого в достижение целей организации. Равные возможности предоставляются каждому для продвижения и прогресса в выбранной карьере. Некоторые работники провели семинары в пределах государства для популяризации их профессии. Итак, нашим исследованием рекомендуется, чтобы управленческие кадры улучшили межличностные отношения между персоналом и руководящей командой для обеспечения повышения производительности.

Ключевые слова: лидерство, организация, поведение, управление и производительность.

\section{References}

1. Abdulraheem I. (2016) An overview of accreditation exercise in Nigeria higher education, (1-10).

2. Ayman R,\&Korabik K (2010) Leadership: Why Gender and Culture Matter, Am Psychology., 63(3):157-170.

3. Beniss W (2007): The challenge of Leadership in the Modern world: Introduction to special Issue. Am Psychol 62(1): 2-5.

4. Bass B.M Avolio, B.J \&Sunny(1993). Transformational Leadership and Organizational Culture.Public Administration quarterly, 113-121.

5. Bass B.M Avolio.BJ., Jung D.I., \&Berson Y (2003). Predicting Unit Performance by Assessing Transformational and Transactional Leadership.Journal of Applied Psychology.88(2).

6. Dale K., Fox M L (2008). Leadership and organizational commitment mediating effect of role stress $J$. Manage Issue, 10 (1):574-590.

7. Jamaludin Z. (2011) Do transactional, transformational and spiritual leadership style distinct? A conceptional insight. Journal of Global Business and Economics, 2(1), 73-85.

8. Ngodo OE (2008) Procedural justice and trust: The linj in the transformational leadership organizational outcome relationship. Intl. J. Lead Stud., 4 (1):82-100.

9. Popoola Mufutau Akanmu (2014). Organization Politics- Implication for managers and employees ( a case study of LOPIN Nigeria Limited Osogbo). Unpublished M.sc seminar paper at National Open University of Nigeria (NOUN). 